\title{
Lessons from Literature: Blending Academic Perspective with Management Practices
}

\author{
Surbhi Kapur (Corresponding Author) \\ School of Management, Campus 7, KIIT University, \\ Patia, Bhubaneswar, 751024, Odisha, India \\ E-mail: surbhi@ksom.ac.in \\ Pooja Mohanty \\ School of Management, Campus 7, KIIT University, \\ Patia, Bhubaneswar, 751024, Odisha, India \\ E-mail: pooja.mohanty@ksom.ac.in
}

Doi:10.7575/aiac.alls.v.5n.5p.233

URL: http://dx.doi.org/10.7575/aiac.alls.v.5n.5p.233
Received: 06/08/2014

Accepted: 13/09/2014

\begin{abstract}
The present paper studies the role literature can play in management in general and in leadership, organizational behavior and communication in particular. Literature normally gets a skeptical reception in management studies. The paper discusses the relevance of literature for a better understanding of human behaviour and a judicious discernment of situations, preferences and consequences. Literature, replete with an array of people and situations either mismanaged or otherwise can then become a potent, instructive and a much more engaging source and tool of teaching. The paper explores the possibility of using literature as a reservoir for focused case studies and issue based excerpts from appropriate works. Shakespeare's famous heroes, Arthur Miller's Death of a Salesman, Joseph Conrad's The Secret Sharer and many more exhibiting leadership challenges, decision making, self-awareness, judgment, ethics, interpersonal conflict and communication can provide meaningful parallels from literature to the modern day managers.
\end{abstract}

Keywords: Literature, Management, Leadership, Organizational Behaviour, Communication

\section{Introduction}

While story telling in management is highly appreciated as an effective tool to connect and motivate, when it is called literature, it becomes a source of discomfiture. Management experts agree that stories are key ingredients of our persuasion pursuits and engagement principles yet literature fails to be their cup of tea. To address this paradox, it is argued that if stories remain with us and engage more than lectures, bulleted points, cold facts, distant data, spreadsheets or logic alone, then the possibility of drawing stories from their biggest source (literature) must be explored. Besides, if "All the world's a stage" and effective communication is theatre, then persuasive speaking (read presentation, group discussion, interview skills), effective writing, empathetic listening (a grossly underrated and neglected skill) and communicating confidently in team, interpersonal and intercultural settings involves performance. And teaching to perform better could include stories to facilitate engagement and "long-term retention" (Choo, 2005). Arguments concealed in illustrative stories penetrate our intellectual defenses, stir our emotions and get permanently etched in our minds. Peter Guber, in his book, Tell to Win, strongly advocates stories in business and uses the Trojan Horse as the principal allegory symbolizing the "purposeful stories" (Guber, 2011). According to the fable the dejected Greeks, tired with "their ten year siege of Troy", feign to return leaving behind a gigantic, hollow wooden horse with soldiers hiding inside. Assuming it to be a gift, the Trojans in triumphant glee, drag the trophy inside the city. The Greek soldiers sneak out of the horse in the night and unleash an orgy of killing, burning and winning. The Trojan horse was a "delivery vehicle in disguise" to ensure entry into the enemy bastion and Guber equates it with stories skillfully crafted and impregnated with "information, ideas, emotional prompts, and value propositions that the teller wants to sneak inside the listener's heart and mind" (Guber, 2011). A story then has the potential to affect our thoughts, reactions, outlook and values. While logical reasoning and expert testimony remain important weapons in the training arsenal of business experts, the impact of fiction in persuading an audience may at times be more. Its role extends beyond the odd mention as a speech opener or as an ice-breaker in a business meeting or training program to an essential ingredient of persuasive communication directed towards organizational goals. Storytelling could be used as a compelling business contrivance to vend a vision or an idea, motivate a team or draw a commitment. It can then become a fundamental instrument in carving a manager's success story. Literature is a storehouse of stories and yet the skepticism and apprehension in its use in curricula is probably housed in a general perception among many business people that literature is a synonym for subjectivism and abstract imagery. Without denying its subjective nature and ambiguity involved, this paper advocates the use of literature with a more focussed approach aimed at fixed objectives 
through appropriate works. The subsequent sections showcase Communication, Organizational Behavior and Leadership lessons that can be learnt through deliberate and designed unveiling of literature.

\section{Communication Lessons from Literature}

Business communication is expected to be clear, concise and objective with a deliberate focus on stating the bottom line or main idea first for most business messages. The instructions are clear. Begin with the main idea, follow by specific details in bulleted points and conclude with a repetition of main idea/request/action desired with a deadline. Fair enough, this leads to easy understanding of clear instructions to people who are the victims of information overload and paucity of time. The ability to categorize information under appropriate headings or provide a short executive summary would be appreciated as a testimony to crisp writing ensuring easy to locate information. But this direct approach or "direct organizational plan" (Lesikar, Flatley, Rentz, Pande, 2010) may not be useful while motivating a disinterested workforce or persuading a hostile group of employees. Though communication experts talk about listing the benefits and logical reasons to ensure persuasive communication, a little story, manipulation of language and a word picture of a brighter future may help achieve more. Literature enters when Shakespeare provides answers to our managers today. Communication lessons to motivate employees in adverse conditions can be learnt from Henry V's legendary speech before the Battle of Agincourt. There can be no motivation more than a visualization of the rewards that are likely to follow. Leaders have successfully inspired their followers by telling them how their work will change things for them and for the organization. Pompous words may not be required to this end, small words of acknowledgement and praise at the right time can inspire employees to do wonders. The secret lies in making each employee feel that he/she is a part of the mission that is bound to succeed if the work is done properly and that the rewards that would follow would immortalize them.

"But he'll remember, with advantages,

What feats he did that day. Then shall our names,

Familiar in his mouth as household words,

Harry the King, Bedford and Exeter,

Warwick and Talbot, Salisbury and Gloucester.

Be in their flowing cups freshly remembered.....

From this day to the ending of the world

But we in it shall be remembered..." (King Henry V,4.3, 49-59)

Further, Marc Antony's speech in Julius Caeser can be a treatise on persuasive speaking, especially on addressing a hostile audience. Brutus' speech which preceded Marc Antony's was replete with logic where Brutus urged the mob to believe him as he was an honourable man and use their reason to judge him. His balanced language reflected his conviction that Caesar's unwarranted ambition outweighed his merits and to prevent an ambitious and tyrannical dictatorship instead of the existing republican form of government, killing Caesar was a necessity. But Marc Antony gained an edge over Brutus' logic by treading initially on safe territory of repetition of Brutus's status as "an honourable man" and Caesar's established over-ambition. Without contradicting Brutus' reason he introduced the germ of skepticism: "If it were so" $(3.2,80)$. He subsequently combined known facts like Caesar's generosity in "filling the general coffers" $(3.2,90)$ and his refusal of accepting the "kingly crown" $(3.2,97)$, vision of the future like the public enjoying Caersar's "private arbours, and new-planted orchards" $(3.2,249)$ left for them and their heirs, questions fanning the doubt like "Did this in Caesar seem ambitious?" and emotion like "When that the poor have cried, Caesar hath wept/Ambition should be made of sterner stuff" $(3.2,91-93)$ and "My heart is in the coffin there with Caesar" (3.2, 107). These potent ingredients which helped Antony achieve a brilliant volte-face could be convincing constituents of a CEO's ineffective oration to persuade. They might not match the dazzling rendition of Shakespeare's heroes but can carefully craft and repeatedly rehearse so that they appear to be responsive and spontaneous. The juxtaposition of reason and logic with suitable emotion can be a lethal combination for an effective delivery. The additional benefit literature provides in the process is the acquired by default ability to recognize implicit meanings from the text and to use language to express in multiple contexts. Hence, Literature teaches to "read between the lines" (Hollet, 1998) and thereby to peep into characters. Moreover, Literature inculcates "an empathetic approach" where students "are able to listen to different voices and respond to those voices...to perceive where the customer is coming from and respond accordingly" (Choo, 2005). Empathy and tolerance towards difference is required for both intercultural and interpersonal communication. Nieragden proposes a shift from "teaching linguistic competence" to aiding "interpersonal and (inter) cultural competence" (Nieragden, 2002) as appreciation of individual preferences and diversity in the workforce is paramount while dealing with clients, customers and colleagues. The words empathy and emotional intelligence are often heard in business corridors and are understood as "the capacity to recognize emotions that are being experienced by another sentient or fictional being" (Wikipedia) yet mere classroom instruction might not be very successful in instilling the same. Moreover, research has revealed 'the existence of 'mirror neurons,' which react to emotions expressed by others and then reproduce them" (Psychology Today). Then literary fiction could provide an insight into behaviour and an improved comprehension of quandary, situations, mistakes and resurgence making them more empathetic and better interpersonal and intercultural communicators. Death of a Salesman could 
provide engaging reading and a lesson in interpersonal skills while the short story called The Circuit by Franciscour Jimenez could help in intercultural education. Literature can thus become a gateway to analysis of characters (read leaders), response to various settings/situations (organisational behaviour), sensitivity and acceptance to responses and differences (interpersonal and intercultural relationship management) and effective use of language (communication). This could be successfully achieved through literary texts carefully selected and case studies assiduously crafted.

\section{Lessons of Organizational Behaviour- values and principles from Literature}

Lessons of values, moral and organizational, can be learnt from various sources of literary works created by writers from all the eras. Shakespeare's plays like Macbeth and Othello teach us important lessons in this context. These Tragedies demonstrate the grievous mistakes even people with profound understanding commit in confusing and challenging situations. In Othello, the conflict is internal that influences the perception of the protagonist who is affected to the extent of analyzing things in an altogether different light (Al-Amin, 1999). Because of this the value system of the person is affected in various aspects like, loss of faith and development of unreasonable doubts in other characters. The present play was written to instill a sense of equality among the people irrespective of race and ethnicity and to spread across the message that all are same as far as the basic human nature is concerned (Jones, 1994). In an organization various people from diverse vicinity work together towards one shared vision. Hence, it becomes important to develop a value system that is conducive to all. People in the organization do not just need to work in teams; rather, they need to work effectively towards achieving the goal of the organization. Hence, a value system that is beyond all differences has to be inculcated in the individual members of the organization. From the different plays like the one cited above, invaluable learnings of values can be received and inculcated.

Shakespeare's Macbeth also teaches us the importance of the ability to differentiate between certain things that lead us to certain definite results- the ability to understand where to stop and the ability to take decision. Decision-making is a very important aspect of management. Hence, learning the skill becomes extremely important. Macbeth, the protagonist of the play has a tragic flaw of 'vaulting ambition' and hence fails to take the right decision at the time of need and falls into the trap of the moral evil and hence fails ultimately.

"Double, double, toil and trouble..." (Macbeth, 4.I.IO)

An excess of ambition results in a wrong decision and the protagonist then suffers from moral turmoil and fails subsequently. This particular play can be a source of learning, especially for the art of decision-making, for the management students who are in the pursuit of acquiring various management skills. 'Humanistic' is the word coined for Macbeth by the researcher/s, Bana e Costa et al, to explain how decision makers ponder, communicate and discuss their value system and preferences. They also call it 'Interactive' and 'constructive'. These are, without doubt, very important facets of management studies. Hence, Literature can help students learn management lessons.

To extend it further, contemporary literature also demonstrates a lot of vital issues, like lack of decision making skills, interpersonal skills, ethics, values and managerial skills which can be adopted by the students of management studies. For instance, Arthur Miller's Death of a Salesman and All My Sons teach many such lessons. Values and more specifically the lessons of ethics that have been decaying immensely in pursuit of the big American dream (Heyen, 1988) are taught in these works. These lessons could help the students inculcate an overall understanding of successfully working in an organization towards attainment of the goal of the organization.

\section{Leadership alternatives from the Bard and Conrad's Secret Sharer}

The success of the leader lies in being able to identify the capabilities of his team members and the limits that they can achieve if they are provided with the right path and motivation. He needs to lead them as a general would lead his army to victory with the right strategy and encouragement so as to bring out the best in his followers towards achieving the objectives of the organization. But the path to these lofty aims could be replete with obstacles beginning with joining as a new leader in an organization. The "new boss is a foreign substance injected into a living organism" (Whitney, Packer, 2000). If you are the intruder who has newly joined an organization you may have grabbed the position of old timers who probably had set their eyes on the chair and thought they were more suitable considering their familiarity with procedures and equations with authority. So naturally they would resent you surreptitiously or may voice their umbrage candidly and would either way not miss an opportunity to destabilize you. Others who probably do not have anything against you but are aware of the undercurrents would also be observing from the sidelines. In both the scenarios, the outsider becomes the focus of critical attention and scrutiny. So a good strategy would be to shift the attention of these "Busy giddy minds" (Henry IV, 4.5, 212-13) towards "foreign quarrels" or existing conundrum and pressing issues. With more time being devoted towards work on hand, little time to plot and plan against you would be left. This could be an initial step to bring together detractors and supporters just like Henry V's Battle of Agincourt against France which united England. The people who seem to fall in the category of supporters or appear to be happy with your success should be befriended and included in your team of apparent faithfuls. Constructing a new team, which is like sifting pearls from the debris, could be the initial aim. So like the erstwhile kings mingling with the commoners, moving out of the office (a storehouse of sieved and sifted information) could prove useful. Henry V did it and learnt a lot observing the subjects and their reactions to situations. Employees feeling left out might like the interest exhibited in them. Winning their confidence through close coordination would reveal their pluses and minuses - their proficiency and the opposite, their suitability or otherwise. Once you are able to form/perceived to have formed a nuclear group of loyalists (however small it may be), the fence sitters will tend to get attracted towards you. Even the diehard antagonists will display a softening of their stand on various issues. This situation has to be exploited to become 
the undisputed leader. But a word of caution: the groups can realign at the smallest provocation. The ice is yet to set. Hence play on and in the process of working together assess their dependability and dexterity.

Henry V's historical speech on the eve of the Battle of Agincourt rouses and stirs his troops and us almost equally. His small band of men as compared to the large French army is motivated no end by the King's "We few, we happy few, we band of brothers" (King Henry V, 4.3, 56-60). The message is clear, never miss a chance to encourage your band buoy up the boys. Espouse them to win them because you need the support more than them. It's lonely at the top and often you may need that sound advice which probably an old hand or a wise veteran may provide. After the extraordinary and unbelievable triumph against the French, Henry V is solicited "to appoint" his "council" to discuss and settle the armistice. Henry trusts his loyalists and gives the authority to "...uncle Exter" and Clarence, Gloucester, Warwick and Huttingdon to "go with the king" with the

“... free power to ratify,

Augment or alter, as your wisdoms best

Shall see advantageable for our dignity,

Anything in or out of our demands,

And we'll consign thereto..." (King Henry V, 5.2, 83-90)

Normally trust invested in others begets trust in you. The risk of a serpent notwithstanding, affiliations may be required sometimes. When the leader is convinced that he/she and the trusted few value organizational benefit over their narrow, personal gains, remarkable results are achieved.

The peril involved in disregarding the sound advice of a trusted right hand and in blindly following the advice of an apparent loyalist can be huge. For example Lear's frenzied fury leading to his wrong decision of disinheriting the deserving daughter Cordelia and his failure to appreciate the wisdom and truth of his adviser Kent's objection leads to his doom. Kent tries hard to drive sense into him:

“... in thy best consideration check

This hideous rashness" (King Lear, 1.1, 150-52)

He has to arbitrate "when majesty falls to folly" and like a true well wisher and a trusted aide he has to tell him in plain words "thou dost evil". Lear, in his blind rage, fails to understand the prudent counsel and banishes Kent mercilessly which results in pandemonium, dark tragedy and Lear's insanity.

In total contrast are the "I am not what I am" (Othello, 1.1, 64) kind of aides like Iago, who pretend to epitomize "love and duty" but are quite the opposite. This most vicious conniver could have parallels of various shades amongst modern day seconds in command, some a shade less or some as manipulative. No leader can ever be loved by all. There are bound to be some detractors who would, at the slightest opportunity, dethrone, or at least try to dethrone the leader. A classic case is that of Iago in Shakespaeare's Othello. He was the third-in-command in the army and had served the King with commitment and sincerity, won wars and also had the recommendation of the "three great ones" of the City of Venice for promotion as the second-in-command. However, Othello overlooked him and made Micheal Cassio the second-in-command of the army apparently only because he was a "great arithmetician". Iago could not forgive Othello for this and began to nurse a great desire for revenge. So the performance of following the leader continues but the veracity of his words "in following him [Othello] I follow but myself" is never lost. Every leader, in choosing his team, has to remove some and promote others. In the process he is bound to create Iagos who will be baying for his blood. The task that follows is to eliminate them from the system or to minimize their damage potential. The former is rife with the dangers of spreading discontent while the latter can leave the threat simmering. Carefully identify the potential "Iagos", talk to them, explain your stand and encourage them to try next time. Being focussed on the job and having trusted employees will make things difficult for such discontented employees. If you feel that they are not going to fall in line, help them to find alternative jobs. Othello may have been able to prevent Iago from becoming virulent by talking and explaining to him. Thus, either encourage the Iagos to join the contest for the promotion in the next round or fire them. They can make the leaders more vulnerable if they are allowed to continue unattended.

Through the Shakespearean mirror we can "see patriarchs like King Lear, clinging to power for too long and then giving the power to the wrong people; we see laggards like Hamlet, that are afraid of actually doing something and do nothing until the ground disappears beneath their feet, we see careerists like Macbeth, for whom power is a goal in itself without ultimately knowing what to do with this power, and we see manipulators like Marc Antony, who uses persuasive rhetoric to sell the literal fridge to the Eskimo" (Etzold, 2012). Henry V with his stirring speech charging his troops, his inspirational team handling and people friendly practical strategy could be called the greatest leaders of Shakespeare and provide fodder for managers on what to do. Unlike him Coriolanus' pride preventing him from reaching out to the people and embracing change, Macbeth's "vaulting ambition" gone wrong, Lear's inability to appreciate his loyal aide Kent's advice, Othello's failure to see through Iago, Hamlet's "analysis-paralysis" and inaction, can demonstrate to the managers what not to do. In a nutshell, plummeting profits need rallying the troops like King Henry V, hostile employees need Mark Antony's brilliant funeral oration and King Lear could help formulate a succession theory warning us of the perils of obsequiousness and the price of ignoring the wisdom of old hands. The list 
is endless. Delving deep into the recesses of Literature reveals the unfolding of old wisdom still so relevant in modern times because "all the intrigues, the small and big power plays were and are made by men. By managers and executives, who no longer dress like the kings and dukes of Shakespeare's plays, but who seem to be identical to the immortal heroes of Shakespeare in their success, their victories and their defeats" (Etzold, 2012).

Shakespeare's firmament, replete with his abundant assortment of successful and unsuccessful leaders, is not the solitary source of leadership lessons in literature. Short stories like Joseph Conrad's The Secret Sharer give an unconventional perspective of leadership which can be easily identified and understood by managers. The story has a compelling potential to make business leaders reflect on critical decisions that they have taken in the past and the discernment of their impact on their careers. The dichotomy in the mind between empathy and organizational responsibility depicted in the text can flood their minds with similar situations that they have confronted and thus helps them to identify with the protagonist. Freshly appointed, probably as an undue favour, the young captain of a ship returning to Britain from the South-East feels alien amidst unfamiliar workmen: "...I knew very little of my officers...what I felt most was being a stranger to the ship..." (Conrad, 2007). The loneliness at the top coupled with accountability can be an uncomfortable combination. One night, when he chooses to patrol the deck himself, a decision that he later regrets, he allows a naked man to climb on to the ship and hears his story. Gradually, he begins to identify himself with the stowaway, shields and nourishes him and ultimately even helps him escape. The story evokes a host of questions like whether it was right to risk his new job and his men to shield a criminal who had killed a fellow seaman for insubordination (even if it happened in the process of averting disaster for his ship, the Sephora). The Secret Sharer "suggests that there are certain moments in our lives when extravagant, irresponsible gestures become necessary if we are to continue to grow... Their development necessitates departures from the established ethos... and the conventional ethical coordinates that map our prescribed actions" (Vargish, 2010)

\section{Conclusion}

Literature is still perceived as an unlikely instrument with scant potential to be effective in management practices. Mathematical scrupulousness in Management Studies serves excellent purpose in pecuniary judgment and fiscal deficits but not when the nuances of leadership and organizational behaviour are to be understood. Literary fiction provides a wide gamut of examples to choose from and can be as effective as domain instruction or maybe more. In the current, capricious business scenario where attrition is a reality and retention a challenge, managing people and situations gain prime importance. Trouble in most business situations can be traced back not so much to lack of information but to poor appreciation of people and developing situations. Literature offers a plethora of possibilities with its treasure trove of situations and characters ready to be dissected and reveal multiple lessons on leadership, organizational behaviour and of course communication.

\section{References}

Al-Amin, Z. (1999). Othello: The Tragedy of Human Nature, English 1102, Instructor Steven Hale

Choo, L. M. (2005). A case for using literature to teach business English, National University of Singapore, pp. 4-31 [Online] Available: http://www.nus.edu.sg/celc/publications/LimVol4.pdf

Conrad, J. (2007). The Secret Sharer, The Portable Conrad, ed. Michael Gorra. New York: Penguin Classics, 10, 9.

Guber, P. (2011). Tell to Win: Connect, Persuade, and Triumph with the Hidden Power of Story, Crown Business, 1st Edition, Crown Business, 24-38

Heyen, W. (1988). Arthur Miller's Death of a Salesman and the American Dream. Arthur Miller's Death of a Salesman. Ed. Harold Bloom. New York: Chelsea House, 47-58.

Hollet, V. (1998). Effective communication. English Teaching Professional, 8, 18-19.

Psychology Today, [Online] Available: http://www.psychologytoday.com/basics/empathy. Retrieved September 4, 2014.

Jimenez, F. (1997). The Circuit, $1^{\text {st }}$ Edition, University of New Mexico Press, USA

Jones, E. (1994). Othello - An Interpretation", Critical Essays on Shakespeare's Othello. Ed., Anthony G. Barthelemy Pub. Macmillan New York, NY, 39-55.

Lesikar, R.V., Flatley, M.E., Rentz, K., Pandey, N. (2010). Business Communication: Making Connections in a Digital World ( $11^{\text {th }}$ Edition $4^{\text {th }}$ reprint) Tata McGraw-Hill, New Delhi, 131.

Miller, A. (2000). Death of a Salesman, Penguin UK.

Miller, A. (2000). All My Sons, Penguin Classics.

Nieragden, G. (2002). Changing perspective(s): On the 'soft teach' in Business English. IATEFL (International Association of Teachers of English as a Foreign Language), 167, 3-4.

Shakespeare, W. (2010). Henry V, Penguin Books.

Shakespeare, W. (2000). King Henry $I V$, Penguin Group USA.

Shakespeare, W. (2005). Macbeth, Penguin Classics.

Shakespeare, W. (2005). King Lear, Penguin Classics. 
Shakespeare, W. (2005). Othello, Penguin Classics.

Vargish, T., (2010). Conrad's "The Secret Sharer": A Private Ethics of Leadership, War, Literature \& the Arts: An International Journal of the Humanities, Vol. 22(1), 107 [Online] Available: http://www.wlajournal.com/22_12/images/vargish.pdf.

Veit Etzold, (2012). "Power plays: What Shakespeare Can Teach on Leadership", Business Strategy Series, Vol. 13(2), $63-69$.

Whitney, J.O., Packer, T., (2000) Power Plays: Shakespeare's Lessons in Leadership and Management, Simon \& Schuster, NY, USA, 58. 